\title{
Variants of $\beta$-casofensin, a bioactive milk peptide, differently modulate the intestinal barrier: In vivo and ex vivo studies in rats
}

\author{
Jérémie Bruno, ${ }^{\star} †$ Aurélie Nicolas, $\ddagger$ Sandra Pesenti, ${ }^{*}$ Jessica Schwarz,† Jean-Luc Simon, † Joëlle Léonil,‡ \\ and Pascale Plaisancié ${ }^{* 1}$ \\ *Univ-Lyon, CarMeN laboratory, INRA U1397, Inserm U1060, Université Claude Bernard Lyon 1, INSA Lyon, F-69621 Villeurbanne, France \\ †INGREDIA SA, F-62000, Arras, France \\ fINRA, UMR1253 Science et Technologie du Lait et de l'CEuf, Agrocampus Ouest, F-35000 Rennes, France
}

\begin{abstract}
$\beta$-Casofensin is a bioactive milk peptide that modulates the intestinal barrier, particularly through its action on goblet cells. $\beta$-Casofensin corresponds to fragment (f) $94-123$ of the bovine $\beta$-casein $(\beta-\mathrm{CN})$ A2 variant. Fifteen genetic variants of bovine $\beta-\mathrm{CN}(\mathrm{A} 1-3$, B-G, H1-2, I-L) are known, of which the A2, A1, and $\mathrm{B}$ forms are the most common. These variants differ from each other by the substitution of one or more amino acids, some of which are localized in f94 to 123. The aim of our study was to compare the intestinal effects of $\beta$-casofensin A2 and its 3 main variants: A1, $\mathrm{A} 3$, and B. For this purpose, a solution $(0.1 \mu M ; 10$ $\mu \mathrm{L} / \mathrm{g}$ of body weight, postnatal d 10-20) containing $\beta$-casofensin A2, one of its variants (A1, A3, or B), or drinking water (control; CT) was administered to rat pups orally. After euthanasia (postnatal d 20), intestinal segments were collected for biochemical and histochemical analysis and also used to determine paracellular permeability to fluorescein isothiocyanate-labeled 4-kDa dextran in an Ussing chamber. We also studied the direct effects of $\beta$-casofensin A2 and its A1 variant on the paracellular permeability of jejunum segments of adult rats. $\beta$-Casofensin $A 2$ and its $B$ variant significantly increased the population of goblet cells compared with the CT, A1, and A3 groups. The mucin 2 mRNA level was significantly higher in the $\beta$-casofensin A2 group than in the CT, A3, and B groups. Our results also revealed that the protein expression of zonula occludens- 1 and occludin was reduced in the jejunum of rats in the A1, A3, and B groups compared with the CT group. However, the A1 variant was the only peptide to decrease jejunal permeability compared with the CT group. This variant, tested directly in the apical compartment of an Ussing chamber at a concentration of $0.1 \mathrm{n} M$, also reduced jejunal permeability. In con-
\end{abstract}

Received September 28, 2016.

Accepted January 17, 2017.

${ }^{1}$ Corresponding author: pascale.plaisancie@inserm.fr clusion, the substitution of a single amino acid alters the effect of $\beta$-CN sequence f94 to 123 on goblet cells and on intestinal permeability. A genetic polymorphism of $\beta$-CN can affect the biological activity of peptides derived from this protein. These data should be taken into account in the production of bioactive foods.

Key words: bioactive milk peptide, $\beta$-casein, $\beta$-CN $(94-$ 123), intestinal protection

\section{INTRODUCTION}

The 4 caseins $\alpha_{\mathrm{S} 1}, \alpha_{\mathrm{S} 2}, \beta$, and $\kappa$ account for approximately $80 \%$ of the total protein fraction in bovine milk (in the ratio 38:11:38:13; Bobe et al., 1998). Beside their nutritional functions, these proteins are the source of numerous bioactive peptides, including antihypertensive peptides, antithrombotic peptides, antibacterial peptides, immunomodulatory peptides, antioxidant peptides, mineral carriers, opioid agonists, and antagonists (Nagpal et al., 2011; Nongonierma and FitzGerald, 2015). These peptides are inactive as long as they remain encrypted in the primary structure of intact caseins. They are released during gastrointestinal digestion or food processing (for example during fermentation), enabling some to be active in the gastrointestinal tract or in the body after absorption. These milk peptides are therefore good candidates for the development of novel functional foods (Lien and Lowman., 2003). $\beta$-Casofensin is one such promising component for the maintenance of intestinal health (Plaisancié et al., 2013, 2015). It interacts with intestinal goblet cells, an epithelial cell population that plays a crucial role in intestinal protection by producing mucin 2 (MUC2; Plaisancié et al., 2013; Bessette et al., 2016); MUC2 is the main component of intestinal mucus, which provides dynamic protection against the aggressive luminal environment (which includes gastric acid and proteases; Pelaseyed et al., 2014). Interestingly, oral administration of $\beta$-casofensin to healthy rats significantly increased expression of $\mathrm{Muc2}$ mRNA, as well as the population of goblet cells along 
the intestinal tract (Plaisancié et al., 2013). More importantly, $\beta$-casofensin had protective effects against indomethacin-induced enteritis in rats, suggesting that this bioactive peptide is a suitable candidate for the development of novel functional foods to fight against intestinal diseases.

$\beta$-Casofensin, which is encrypted in bovine $\beta$-CN, is not released by human digestive enzymes of the intestinal tract, but by lactic-acid bacteria in some fermented dairy products (Plaisancié et al., 2013). Furthermore, the 4 caseins are characterized by a high genetic polymorphism, leading to different genotypes in milk. Bovine $\beta-\mathrm{CN}$, which comprises 209 amino acid residues, is thus characterized by a total of 15 variants (A1-3, B-G, H1-2, I-L) resulting from amino acid substitutions (Bobe et al., 1998; Caroli et al., 2009; Gallinat et al., 2013). It should be noted that the most common variants in cattle breeds are $\beta-\mathrm{CN}$ A1 and A2; the B variant is less frequent and the others are rare (Caroli et al., 2009). $\beta$-Casofensin (GVSKVKEAMAPKHKEMPFPKYPVEPFTESQ) corresponds to fragment (f) 94 to 123 of $\beta-\mathrm{CN}$ variants $\mathrm{A} 2, \mathrm{C}, \mathrm{D}, \mathrm{E}, \mathrm{F}, \mathrm{H}$, and I. In the current study, we designated this peptide $\beta$-casofensin, or variant A2. In $\beta-\mathrm{CN}$ f94 to 123 of variants $\mathrm{A} 1$ and $\mathrm{G}$, a glutamine is found at position 117, compared with the glutamic acid of the A2 variant. We designated this sequence $\beta$-casofensin variant $\mathrm{A} 1$. In the sequence of $\beta-\mathrm{CN}$ variant $\mathrm{A} 3$, a histidine to glutamine substitution occurs at position 106 ( $\beta$-casofensin A3). Finally, the $\beta$-casofensin variant $\mathrm{B}$ is characterized by an arginine in position 122 compared with the serine of the A2 variant.

The objective of our study was to examine the effect of $\beta$-CN polymorphisms on the bioactivity of f94 to 123. For this purpose, we compared the effects of $\beta$-casofensin A2 on goblet cells with those of its 3 main variants $\mathrm{A} 1, \mathrm{~A} 3$, and $\mathrm{B}$. As $\beta$-casofensin $\mathrm{A} 2$ has 2 methionine residues, we also aimed to determine whether the oxidized peptide retains its activity on intestinal goblet cells. Finally, as tight junctions are a major actor of epithelial integrity, we have also included their study in our experiments. Indeed, the tight junctions connect the adjacent epithelial cells and regulate paracellular permeability. These complex structures comprise more than 50 proteins and consist of transmembrane proteins (occludin and claudins) and cytoplasmic scaffolding proteins (zonula occludens-1, 2, and 3). Among claudin members, claudin- 1 and claudin- 7 are expressed in the jejunum of rat (Markov et al., 2010). We focused our study on the jejunum because $\beta$-casofensin is well known to exert strong effects in this intestinal segment. The chosen peptides were obtained by chemical synthesis and tested in vivo in young rats and ex vivo on jejunum segments of adult rats.

\section{MATERIALS AND METHODS}

\section{Animal Studies}

All experimental protocols were approved by Autorisation de Projet Utilisant des Animaux. A des fins Scientifiques \#4801-2016040514284835 and conducted in accordance with European Commission (2010). $\beta$-Casofensin (also named variant A2) and its variants A1, A3, and B were synthesized by Genecust (Dudelange, Luxembourg). Primiparous Wistar female rats and male Wistar rats were obtained from Janvier (Le Genest-St-Isle, France) and maintained in an airconditioned atmosphere with a 12-h light-dark cycle and free access to tap water and food.

\section{Study Design}

Experiment 1: Administration of $\beta$-Casofensin or Variants. Primiparous Wistar female rats were individually housed with their rat pups. Rat pups received a daily oral administration $(10 \mu \mathrm{L} / \mathrm{g}$ of $\mathrm{BW}$, $0.1 \mu M$ ) of variant A2 (A2 group), variant A1 (A1 group), variant A3 (A3 group), variant B (B group), or drinking water (control group; CT) from postnatal day (PND) 10 to 20 ( $\mathrm{n}=8 /$ group). Treatment was delivered at the same time every day to minimize the effects of circadian rhythm. At 240 min after the final administration, rats were deeply anesthetized with pentobarbital sodium. Intestinal segments were mounted in Ussing chambers (Harvard Apparatus, Holliston, MA) to evaluate paracellular permeability to fluorescein isothiocyanate-labeled 4-kDa dextran (FD4; SigmaAldrich, St. Louis, MO) or harvested for microscopic and biochemical analysis (Figure 1A).

Experiment 2: Effects of $\beta$-Casofensin Variants Applied Directly. Male Wistar rats (200-300 g) were acclimated $5 \mathrm{~d}$ before the study, and then fasted the day before the experiment. Rats were killed at $d$ 6 and the jejunum was removed and placed in KrebsRinger Bicarbonate Buffer (KRB, Sigma-Aldrich; Figure 1B).

Experiment 3: Administration of Variant A2 or Oxidized $\beta$-Casofensin to Young Rats. Primiparous Wistar female rats were individually housed with their rat pups. Rat pups received a daily oral administration $(10 \mu \mathrm{L} / \mathrm{g}$ of $\mathrm{BW}, 0.1 \mu M)$ of a solution containing the $\mathrm{A} 2$ variant, the oxidized $\mathrm{A} 2$ variant (A2OX), a mixture of A2/A2OX (50/50), or drinking water (CT) from PND 10 to 20. Treatment was delivered at the same time every day to minimize the effects of circadian rhythm. At 240 min after the final administration, rats were deeply anesthetized with pentobarbital sodium. Intestinal segments were harvested 


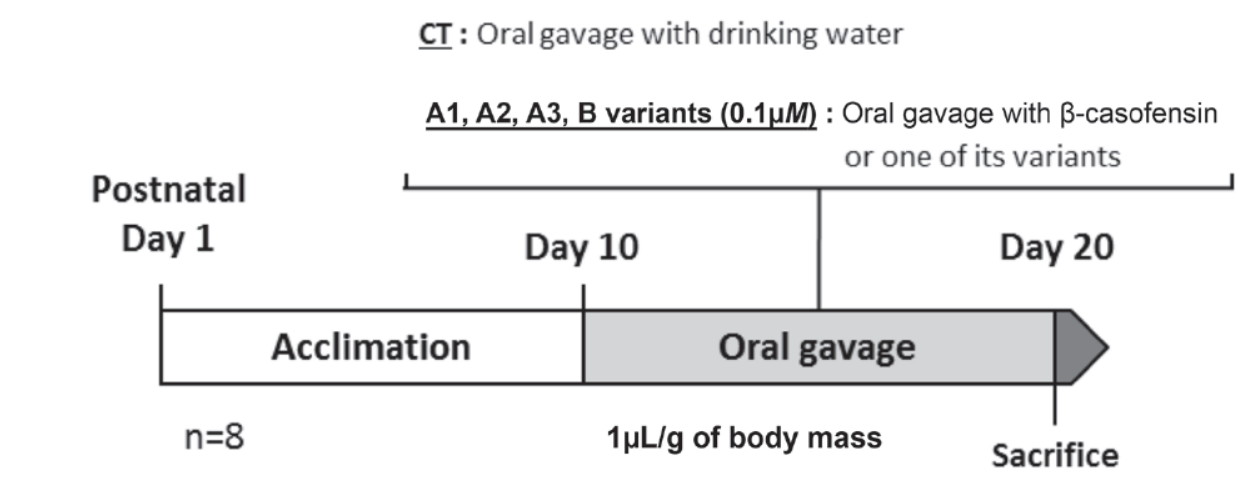

B

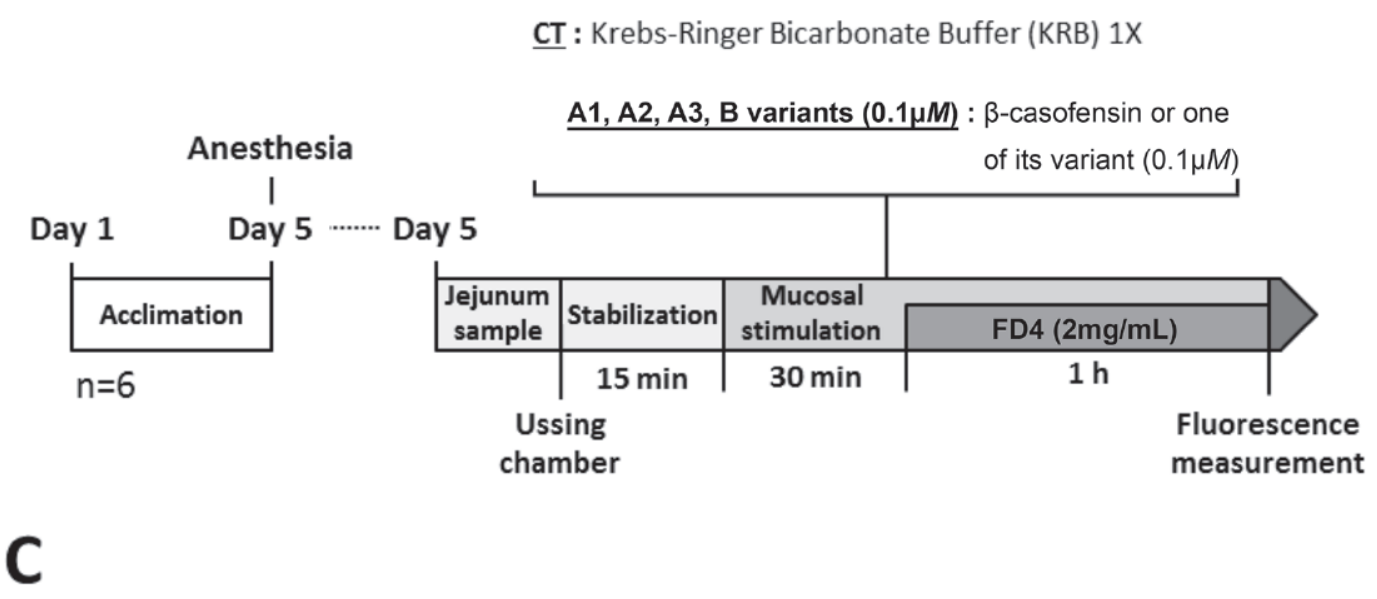

CT : Oral gavage with drinking water

A2, A2OX, A2/A2OX 0.1 $\mu M$ : Oral gavage with A2, oxidized A2

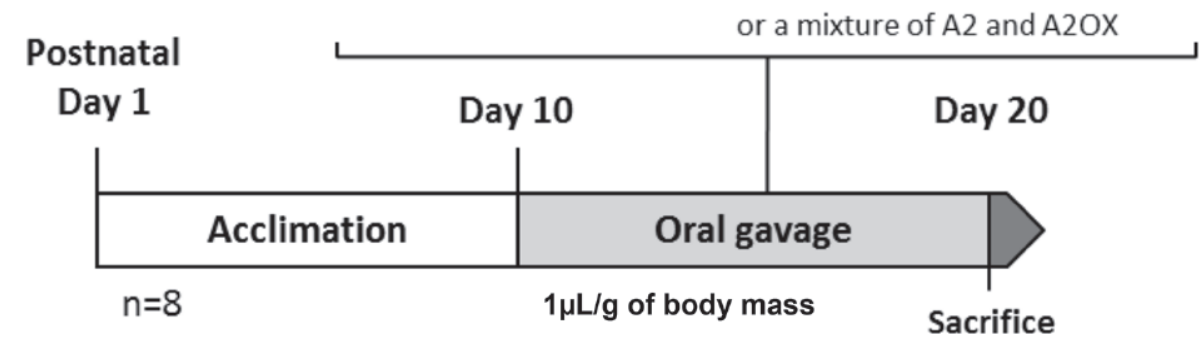

Figure 1. Experimental protocols (A), where rat pups received a once-daily gavage $(10 \mu \mathrm{L} / \mathrm{g}$ of $\mathrm{BW}, 0.1 \mu M)$ of a solution containing $\beta$-casofensin (A2), one of its peptide variants, or drinking water (control group, CT) from postnatal day (PND) 10 to 20 . At 240 min after the final administration, rats were deeply anesthetized with pentobarbital sodium. Jejunal samples were taken for histological and biochemical studies. $\mathrm{n}=8$ /group. (B) Untreated adult rats were deeply anesthetized with pentobarbital sodium. Jejunal samples were taken for study in Ussing chambers (Harvard Apparatus, Holliston, MA) to measure the passage of FD4 from the mucosal compartment to the serosal compartment. After a 15-min stabilization in KRB $1 \times, \beta$-casofensin $(0.1 \mathrm{n} M)$, its variant $\mathrm{A} 1(0.1 \mathrm{n} M)$, a mixture of variants $\mathrm{A} 1$ and $\mathrm{A} 2(50 / 50)$ at $0.1 \mathrm{n} M$, or KRB $1 \times$ (CT segment) was added to the mucosal compartment for a 30-min stimulation. The FD4 (2 mg/mL) was then added to the mucosal compartment for a 1-h stimulation to measure the jejunal paracellular permeability, $\mathrm{n}=8 /$ group. (C) Rat pups received a once-daily gavage (10 $\mu \mathrm{L} / \mathrm{g}$ of BW, $0.1 \mu \mathrm{M}$ ) of a solution containing $\beta$-casofensin (A2), $\beta$-casofensin oxidized (A2OX), a mixture of A2/A2OX, or drinking water (CT group) from PND 10 to 20 ( $\mathrm{n}=8$ /group). At 240 min after the final administration, rats were deeply anesthetized with pentobarbital sodium. Jejunal samples were taken for histological and biochemical studies. A2 = A2 variant; A1 = A1 variant; A3 = A3 variant; B = B variant; FD4 = fluorescein isothiocyanate-labeled 4-kDa dextran (Sigma-Aldrich, St. Louis, MO); KRB = Krebs-Ringer bicarbonate buffer (Sigma-Aldrich). 
and mounted in Ussing chambers to evaluate paracellular permeability to FD4 or used for microscopic and biochemical analysis (Figure 1C).

In order to limit the number of animals, experiments 1 and 3 were carried out at the same time. We therefore treated the following groups on the same days: $\mathrm{CT}, \mathrm{A} 2$, $\mathrm{A} 1, \mathrm{~A} 3, \mathrm{~A}, \mathrm{~B}, \mathrm{~A} 2 \mathrm{OX}$, and A2/A2OX (50/50). As a result, group CT and group A2 are common to experiments 1 and 3 .

\section{Ussing Chamber Experiments}

Both hemichambers were filled with KRB continuously gassed with $95 \% \mathrm{O}_{2}$ and $5 \% \mathrm{CO}_{2}$, and warmed at $37^{\circ} \mathrm{C}$, as previously described (Benoit et al., 2015).

Experiments 1 and 3. After $15 \mathrm{~min}$ of equilibrium, epithelial permeability was measured through the mucosal-to-serosal passage of FD $4(2.2 \mathrm{mg} / \mathrm{mL}$ as final concentration), added in the mucosal compartment. After $1 \mathrm{~h}$, permeability was assessed by measuring the fluorescence intensity in the serosal compartment.

Experiment 2. After $15 \mathrm{~min}$ of equilibrium, the jejunum segment was stimulated for 90 min with variant $\mathrm{A} 2$, variant $\mathrm{A} 1$, a mixture of variants $\mathrm{A} 2$ and $\mathrm{A} 1$ $(50 / 50)$, or $\mathrm{KRB} 1 \times(\mathrm{CT}$ segment) in the mucosal compartment. Epithelial permeability was measured through the mucosal-to-serosal passage of FD4 (2.2 $\mathrm{mg} / \mathrm{mL}$ as a final concentration), added in the mucosal compartment after $30 \mathrm{~min}$ of the stimulation (Figure 1B). The fluorescence levels were measured using the Cytation 3 Cell Imaging Multi-Mode Reader (BioTek, Winooski, VT; excitation $=490 \mathrm{~nm}$ and emission $=$ $520 \mathrm{~nm})$.

\section{Histological Examination of Jejunum for Goblet Cells}

Intestinal tissues were removed, fixed in $10 \%$ formalin solution for $24 \mathrm{~h}$, embedded in paraffin blocks, and cut into $4-\mu \mathrm{m}$ sections. Paraffin sections were rehydrated and stained with alcian blue ( $\mathrm{pH} 2.5)$, followed by the periodic acid-Schiff reaction, and then counterstained with hematoxylin, as previously described (Barcelo A et al., 2000). The alcian blue/periodic acid-Schiff method yielded a blue color when mostly acidic mucins were present, purple when neutral mucins were also present, and magenta when mainly neutral mucins were present; the corresponding cells were designated stained mucus cells. All slides were analyzed by a single investigator who was blinded to the treatment groups. For this purpose, 4 to 6 sections were analyzed per rat, and 200 to 300 mucus cells were counted per sample of intestine. The histological features shown are representative of all tissue samples studied.

\section{Western Blot Analysis}

Frozen tissue samples (15 mg) were crushed, and protein and RNA was immediately extracted using the NucleoSpinR RNA/protein purification kit (MacheryNalgel EURL, Hoerdt, France), according to manufacturer's instructions. Proteins $(40 \mu \mathrm{g})$ were separated on Nupage 3 to $8 \%$ Tris acetate gels (Thermo Fisher Scientific, Villebon sur Yvette, France) and transferred onto polyvinylidene difluoride membranes using the Pierce Power Blotter (Thermo Scientific Pierce, Villebon sur Yvette, France). Membranes were incubated with primary antibodies overnight $4^{\circ} \mathrm{C}$ : a rabbit monoclonal anti- $\beta$-actin antibody (1:2000, \#4970 Cell Signaling Technology, Danvers, MA), a rabbit monoclonal anti-occludin antibody (1:2000, ab167161, Abcam, Cambridge, UK), a rabbit polyclonal antizonula occludens-1 (ZO-1) antibody (1:250, 61-7300, Life Technologies, Villebon sur Yvette, France), and a mouse monoclonal anti-Muc2 (1:200, ab118964, Abcam). Bound antibodies were detected using the WesternBreeze Immunodetecting Chemiluminescent System (Invitrogen, Carlsbad, CA). The optical density of the bands was visualized with the Image System (ImageMaster VDS-CL, Amersham Biosciences, Little Chalfont, UK) and densitometrically analyzed using the Quantity One image analysis software (Bio-Rad, Hercules, CA).

\section{Reverse Transcription Quantitative PCR in Jejunal Tissues}

First-strand cDNA was synthesized from $1 \mu \mathrm{g}$ of total RNA in the presence of $100 \mathrm{U}$ of Superscript II (Invitrogen) using a mixture of random hexamers and oligo (dT) primers (Promega, Charbonnières, France). Quantitative PCR assays were performed by using a Rotor-Gene Q apparatus (Qiagen, Hilden, Germany). The TATA-box binding protein mRNA levels were used as an internal control. The following genes were studied with primers as follows: $Z O-1$ (forward $=5^{\prime}$-ACTGCCAGCTTTAAGCCTCC- 3 ; ; reverse $=5^{\prime}$-CCCAGCTCACACGTATTCCT- $3^{\prime}$ ): occludin (forward = 5'-CCACCTATCACTTCAGATCAAC-3'; reverse = 5'-CCCAGCTCACACGTATTCCT-3'); claudin 1 (forward $=$ 5'-TCGACTCCTTGCTGAATCTG-3'; reverse $=5^{\prime}$-TGCTGTGGCCACTAATGTCG-3'); claudin 7 $=$ forward $=5^{\prime}$-CCTGGATTGGTCATCAGATT- ${ }^{\prime}$; reverse $=5^{\prime}$-CCCAGCTCACACGTATTCCT-3'); Muc2 (forward = 5'-ATTACCCCCACAGTGGACAA-3'; reverse = 5'-GGGATGTCCACCACAAGGTT-3'); and TBP (forward $=5^{\prime}$-TGGTGTGCACAGGAGCCAAG-3'; reverse 5'-TTCACATCACAGCTCCCCAC-3'). 


\section{In Silico Analysis}

Variant sequences were submitted to the PEPFOLD server to predict their 3-dimensional structures (Thévenet et al., 2012; Shen et al., 2014). The best models provided by the server were selected for further analyses. Molecular hydrophobicity potential was computed by the Platinum web service (Efremov et al., 2007; Pyrkov et al., 2009) using the Ghose force-field parameters. Electrostatic potentials were computed with the APBS program (Baker et al., 2001; Dolinsky et al., 2004; Dolinsky et al., 2007) using the Charmm force-field and $50 \mathrm{~m} M$ concentrations for both sodium and chloride ions. All models were visualized with VMD (visual molecular dynamics) software (Humphrey et al., 1996).

\section{Statistical Analysis}

All data are presented as mean \pm standard error of the mean. Statistical analysis was performed using Graph Pad Prism 6.0 (GraphPad, San Diego, CA). A one-way ANOVA was used to compare data. If the oneway ANOVA revealed any significant effects, the differences between means were tested with Tukey's multiple comparisons post hoc test.

\section{RESULTS}

\section{Variants of $\beta$-Casofensin (0.1 $\mu$ M) Differently Modulate the Intestinal Barrier}

Effects on Goblet Cells in Rat Pups. Histochemical analysis of the jejunum showed that daily oral administration of the $\beta$-casofensin A2 variant $(0.1 \mu M)$ increased the population of goblet cells compared with the CT group $(P<0.001)$, the A1 group $(P<0.001)$, or the A3 group $(P<0.01$; Figure $2 \mathrm{~A}$ and $\mathrm{B})$; a similar effect was observed with the $\mathrm{B}$ variant. In contrast, no increase in the density of goblet cells was observed after oral administration of the A1 or A 3 variants. We observed comparable effects in the duodenum (Table 1). Finally, only variant B altered the goblet cells population in the ileum compared with the CT group (Table $1)$.

As shown in Figure 2D, we observed a significant difference between the Muc2 mRNA levels in the jejunum of the A2 group and those of the A3 or B groups. Only treatment with the $\beta$-casofensin $\mathrm{A} 2$ variant resulted in a significant increase in Muc2 mRNA levels compared with the CT group $(165.1 \pm 28.3$ vs. $100.0 \pm 10.5 \%$ of the $\mathrm{CT}$ value; $P<0.01)$. We investigated the expression of MUC2 proteins by Western blotting (Figure 2C) and observed no significant difference between variants.
Effects on Intestinal Permeability in Rat Pups. Intestinal permeability represents the functional feature of the intestinal barrier. As shown in Figure 3A, the jejunum segments of the A1 group were characterized by a lower intestinal permeability to FD4 than those of the CT group $(P<0.05)$. In contrast, the jejunal permeability of rat pups receiving oral administration of $\beta$-casofensin A2 or its A3 and B variants was comparable to that of CT rat pups. The difference between the A1 group and the A3 group was significant $(P<$ $0.05)$.

We then investigated the expression of tight junction proteins (TJP) by Western blotting. The protein expression of ZO-1 was reduced in the jejunum of the $\mathrm{A} 1, \mathrm{~A} 3$, and $\mathrm{B}$ groups compared with the CT group (Figure 3B). Moreover, ZO-1 protein expression of the B group was significantly different to that of the A2 group $(P<0.01)$. The protein expression of occludin was also reduced in the jejunum of A1, A3, or B group rat pups when compared with either the CT group or the A2 group (Figure 3D).

Further analysis using quantitative reverse transcription (RT)-PCR showed no modification of the mRNA levels of claudin-1, claudin-7, $Z O-1$, and occludin in the jejunum of rats in the A2 or A1 groups compared with $\mathrm{CT}$ rats (Figure $3 \mathrm{C}$ and E, Table 2). In contrast, we observed a significant decrease in the expression of ZO-1, occluding, and claudin-7 in the A3 and B groups when compared with the A2 or CT groups. None of the tested peptides significantly altered the expression of claudin-1.

\section{Effects of the A1 Variant Directly Tested in an Ussing Chamber}

Because of the decrease in jejunal permeability observed in the A1 group, we decided to investigate the immediate effects of this peptide on the permeability of jejunum ex vivo by directly introducing the peptide into the apical compartment of an Ussing chamber. We also tested our peptide of interest, the A2 variant. The A1 variant $(0.1 \mathrm{n} M)$ significantly decreased intestinal permeability to FD4 compared with CT segments (15.4 \pm 1.8 vs. $100.0 \pm 28.5 \%$ of the $\mathrm{CT}$ value; $P<0.01)$ or to the A2 variant $(0.1 \mathrm{n} M ; P<0.05$; Figure 4$)$. We also observed this effect with a mixture of the A2 and A1 variants at $0.1 \mathrm{n} M(16.6 \pm 1.8$ vs. $100.0 \pm 28.5 \%$ of the $\mathrm{CT}$ value, $P<0.01$ ), whereas the A2 variant was without effect compared with CT segments (Figure 4). The A2 variant was also tested at concentrations of 0.01 and $0.1 \mu M$ with no significant effect on the intestinal permeability of jejunum segments of adult rats (data not shown). 


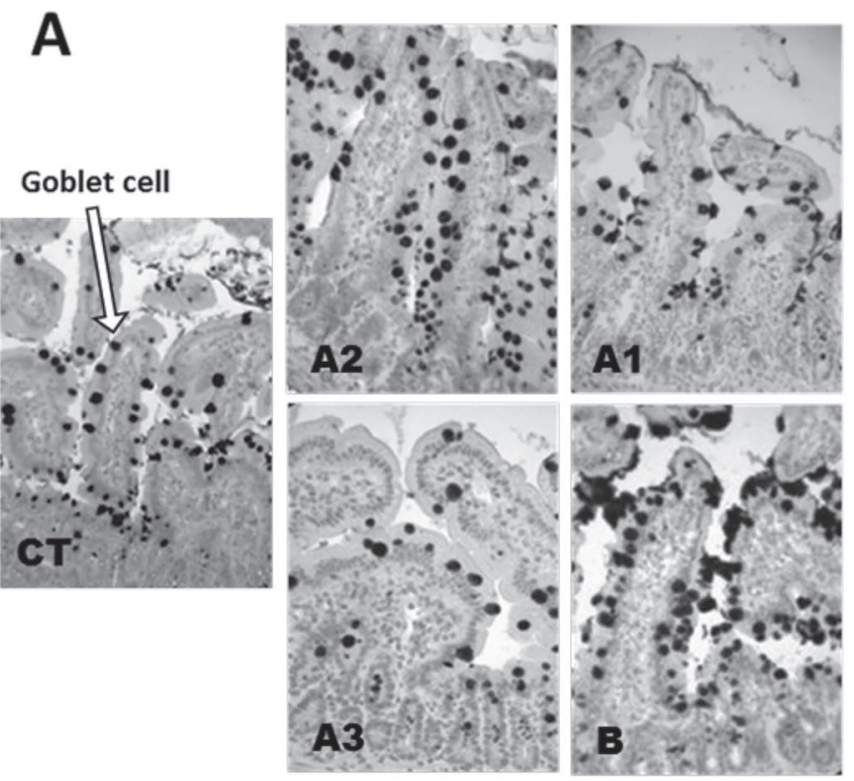

C

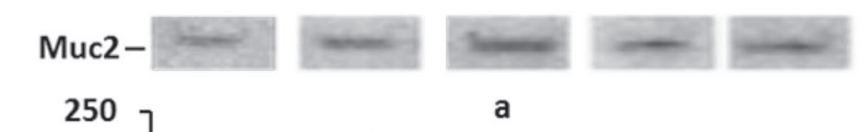

B

D
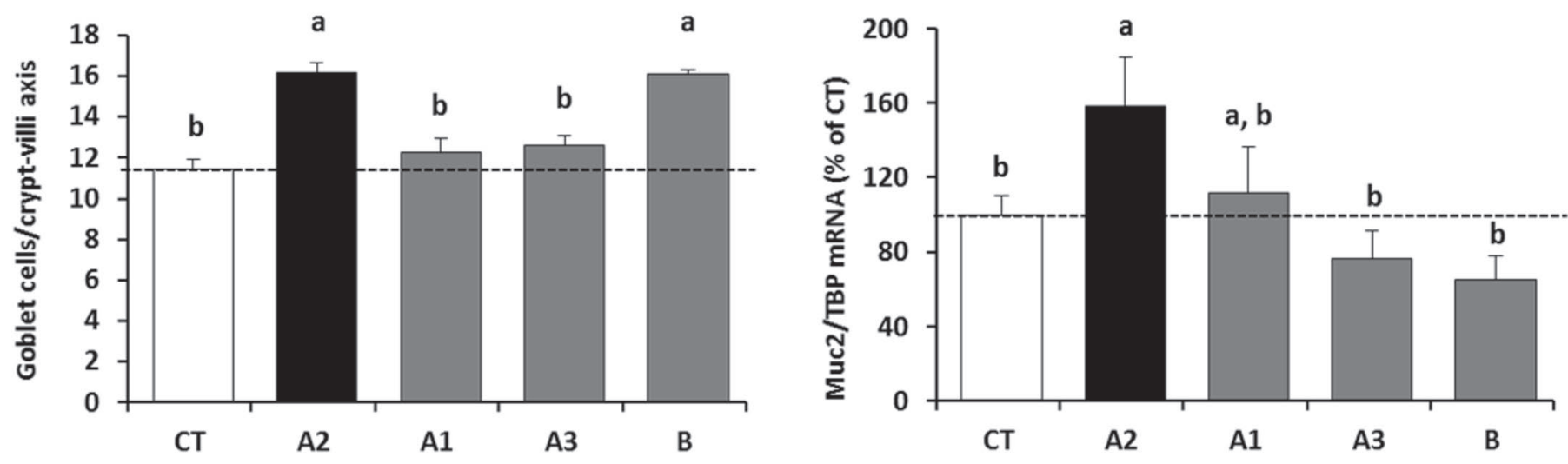

Figure 2. Peptide variants of $\beta$-casofensin $(0.1 \mu M)$ differently modulate intestinal goblet cells and $M u c 2$ expression. Rat pups received a once-daily gavage $(10 \mu \mathrm{L} / \mathrm{g})$ of $\beta$-casofensin $(0.01 \mu M)$, peptide variants of $\beta$-casofensin $(0.01 \mu M)$, or drinking water (CT) from postnatal d 10 to 20. (A) Representative images from the jejunum of CT, A2, A1, A3, and B rats. Numerous goblet cells were observed (arrow; original magnification $\times 20$ ). (B) Mean number of jejunal goblet cells per crypt-villus axis. For this purpose, 4 to 6 sections were analyzed per rat, and 200 to 300 goblet cells were counted per sample of intestine. (C) Expression of Muc2 was determined by Western blotting and normalization to the reference protein level (actin). Representative Western blot picture of Muc2. (D) Real-time PCR analysis of Muc2 mRNA. The expression of Muc2 was normalized to the reference gene level $(T B P)$ in each sample. The results are expressed as percent of control rats. Data are expressed as mean \pm SEM $(n=8 /$ group $)$ and were analyzed by one-way ANOVA, followed by Tukey's multiple comparison test to differentiate the treatments. Means not sharing a common letter $(\mathrm{a}, \mathrm{b})$ differ significantly $(P<0.05)$. For instance, means labeled with "a" were significantly different from those labeled with "b," but were not different from those labeled with "a,b" in the present labeling system. CT = control; A2 = A2 variant; $\mathrm{A} 1=\mathrm{A} 1$ variant; $\mathrm{A} 3=\mathrm{A} 3$ variant; $\mathrm{B}=\mathrm{B}$ variant; the horizontal dashed line indicates the control value.

\section{Effects of Oxidized $\beta$-Casofensin (0.1 $\mu \mathrm{M})$ on the Intestinal Barrier}

Effects on Goblet Cells in Rat Pups. Figures $5 \mathrm{~A}$ and $5 \mathrm{~B}$ show that oxidized $\beta$-casofensin (A2OX) increased the population of goblet cells in the jejunum compared with the CT group (13.31 \pm 0.77 vs. 11.42 \pm 0.51 goblet cells/crypt-villi axis, $P<0.05)$. How- ever, the effect of A2OX was significantly lower than that of $\beta$-casofensin A2. The largest increase in goblet cells was obtained with an A2/A2OX mixture (18.11 \pm 0.48 vs. $11.42 \pm 0.51$ goblet cells/crypt-villi axis vs. CT; $P<0.001$ ). The levels of MUC2 protein were also augmented in the jejunum of the A2/A2OX group when compared with all other groups (Figure 5C). In contrast, a significant decrease in Muc2 mRNA levels 
Table 1. Mean number of goblet cells per crypt-villus axis ${ }^{1}$

Treatment $^{2}$

\begin{tabular}{llllll}
\cline { 2 - 5 } Item & CT & A2 & A1 & A3 & B \\
\hline
\end{tabular}

Duodenum $15.0 \pm 0.2^{\mathrm{b}} \quad 18.8 \pm 0.9^{\mathrm{a}} \quad 14.5 \pm 1.0^{\mathrm{b}} \quad 15.8 \pm 1.2^{\mathrm{b}} \quad 19.9 \pm 0.5^{\mathrm{a}}$

$\begin{array}{llllll}\text { Jejunum } & 11.4 \pm 0.5^{\mathrm{b}} & 16.2 \pm 0.5^{\mathrm{a}} & 12.3 \pm 0.7^{\mathrm{b}} & 12.6 \pm 0.5^{\mathrm{b}} & 16.1 \pm 0.2^{\mathrm{a}}\end{array}$

Ileum $\quad 11.7 \pm 0.5^{\mathrm{b}} \quad 11.7 \pm 0.3^{\mathrm{b}} \quad 10.1 \pm 0.8^{\mathrm{b}} \quad 10.8 \pm 0.7^{\mathrm{b}} \quad 15.4 \pm 0.4^{\mathrm{a}}$

$\overline{\mathrm{a}, \mathrm{b}}$ Labeled means within a row without a common letter differ, $P<$ 0.05 , according to one-way ANOVA followed by Tukey's multiple comparisons test.

${ }^{1}$ Data are expressed as mean $\pm \mathrm{SEM}, \mathrm{n}=8$ /group.

${ }^{2} \mathrm{CT}=$ control; $\mathrm{A} 2=\mathrm{A} 2$ variant; $\mathrm{A} 1=\mathrm{A} 1$ variant; $\mathrm{A} 3=\mathrm{A} 3$ variant; $\mathrm{B}=\mathrm{B}$ variant of $\beta-\mathrm{CN}$.

was found in the jejunum of the A2OX group when compared with other groups (Figure 5D).

Histochemical analysis also showed that the A2OX peptide did not increase the goblet cell population in the duodenum, whereas the A2 peptide induced such an increase (Table 3). Moreover, administration of the A2/A2OX mixture was the only treatment that induced hyperplasia of goblet cells throughout the small intestine (Table 3).

Effects on Intestinal Permeability in Rat Pups. As shown in Figure 6A, no difference was observed in jejunal permeability between the groups. The protein expression of ZO-1 was significantly increased in the A2OX group compared with all other groups (Figure $6 \mathrm{~B})$. In contrast, the $\mathrm{A} 2 / \mathrm{A} 2 \mathrm{OX}$ mixture reduced the protein expression of ZO-1 compared with the $\mathrm{CT}$ group and also the mRNA level of ZO-1 compared with the $\mathrm{A} 2$ group (Figure $6 \mathrm{~B}$ and $\mathrm{C}$ ). We also observed that the $\mathrm{A} 2 \mathrm{OX}$ variant and the A2/A2OX mixture significantly decreased the protein expression of occludin in the jejunum of rat pups compared with the CT and A2 groups (Figure 6D) and their mRNA levels compared with the A2 group (Figure 6E). Finally, quantitative RT-PCR analysis detected decreased levels of claudin- 1 and -7 mRNA in the jejunum of the A2OX group compared with the $\mathrm{CT}$ and $\mathrm{A} 2$ groups (Table 4). In addition, the level of claudin-7 mRNA was decreased in the jejunum of rat pups treated with the A2/A2OX mixture compared with the CT group $(77.4 \pm 6.0$ vs. $100.0 \pm 6.4 \%$ of the $\mathrm{CT}$ value; $P<0.05$; Table 4$)$.

\section{DISCUSSION}

We have previously demonstrated that $\beta$-casofensin acts upon the intestinal barrier and can prevent gut dysfunctions (Plaisancié et al., 2013, 2015; Bessette et al., 2016). The purpose of our study was to determine whether a single amino acid substitution in the $\beta$-casofensin sequence could alter its intestinal effects. Our results showed that $\beta$-casofensin and each of its
3 natural variants triggered a different intestinal barrier response. First, $\beta$-casofensin (A2) and its B variant were the only peptides able to increase the goblet cell population. As, $\beta$-casofensin A2 mainly modulates the intestinal defense through its action on goblet cells, the genetic polymorphism of $\beta$-CN can strongly influence the intestinal health properties of dairy products. This is all the more important, as $\beta-\mathrm{CN} \mathrm{A} 1$ is one of the 2 main variants of this milk protein. Second, the A1, $\mathrm{A} 3$, and $\mathrm{B}$ variants decreased the expression of TJP, which was not the case for $\beta$-casofensin. Finally, the A1 variant was the only peptide to decrease intestinal permeability. Our results suggest that the substitution of a single amino acid can modify the effects of bioactive peptides. These data are consistent with those of Weimann et al. (2009), which demonstrate that 2 variants (A-S-P and V-S-P), corresponding to f148 to 150 of $\kappa-\mathrm{CN}$ (B, C, or F1), do not have the same inhibitory effect on the angiotensin I converting enzyme, with an IC50 value (equivalent to the micromolar concentration of peptide mediating a $50 \%$ inhibition) of 242.3 and 21.8, respectively. Similarly, Tulipano et al. (2010) showed that 2 variants of a peptide produced by proteolysis of $\alpha_{\mathrm{S}_{2}} \mathrm{CN}$ variants $(\mathrm{C}$ or $\mathrm{A}, \mathrm{B}, \mathrm{D})$ had different effects on osteoblast-like cells.

The tight junction is the key structure regulating intestinal permeability. In our study, we found that the A1 variant reduced the intestinal permeability despite a decreased expression of TJP (ZO-1, occludin). This result runs against the inverse correlation between the expression of TJP and intestinal permeability that is generally accepted (Noth et al., 2011). However, it should be noted that occludin or ZO-1 knockout mice fail to display defective respiratory, renal, or intestinal barrier function, thus suggesting that the loss of these TJP can be overcome (Umeda et al., 2004; Schulzke et al., 2005). In agree with this hypothesis, the TJP are now considered as families with some redundant contributions to tight junction regulation. Two families of transmembrane proteins have been thus identified: claudins (27 members in mammals) and tight junctionassociated MARVEL proteins (occludin, tricellulin, and MarvelD3; Schulzke et al., 2012). It should be added the family of cytoplasmic scaffolding proteins: ZO-1, ZO-2, ZO-3, cingulin, and so on (Lee, 2015). Several studies also suggest many transmembrane proteins are not yet fully characterized (Mineta et al., 2011). Besides the large number of proteins that can be involved, it must be pointed out that the organization and localization of proteins in the tight junction complex also play an important role in regulating intestinal permeability. For example, a change in the localization of occludin in the intestinal epithelium increases paracellular permeability to lactulose and mannitol in mice (Noth et al., 
A

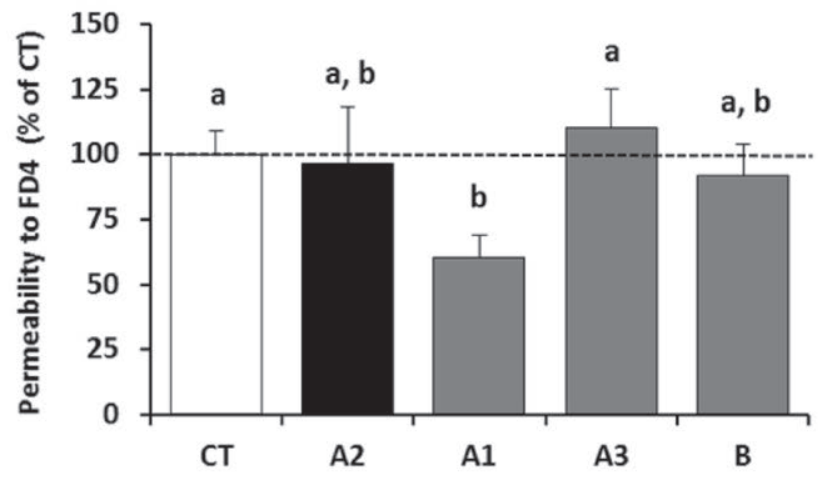

B
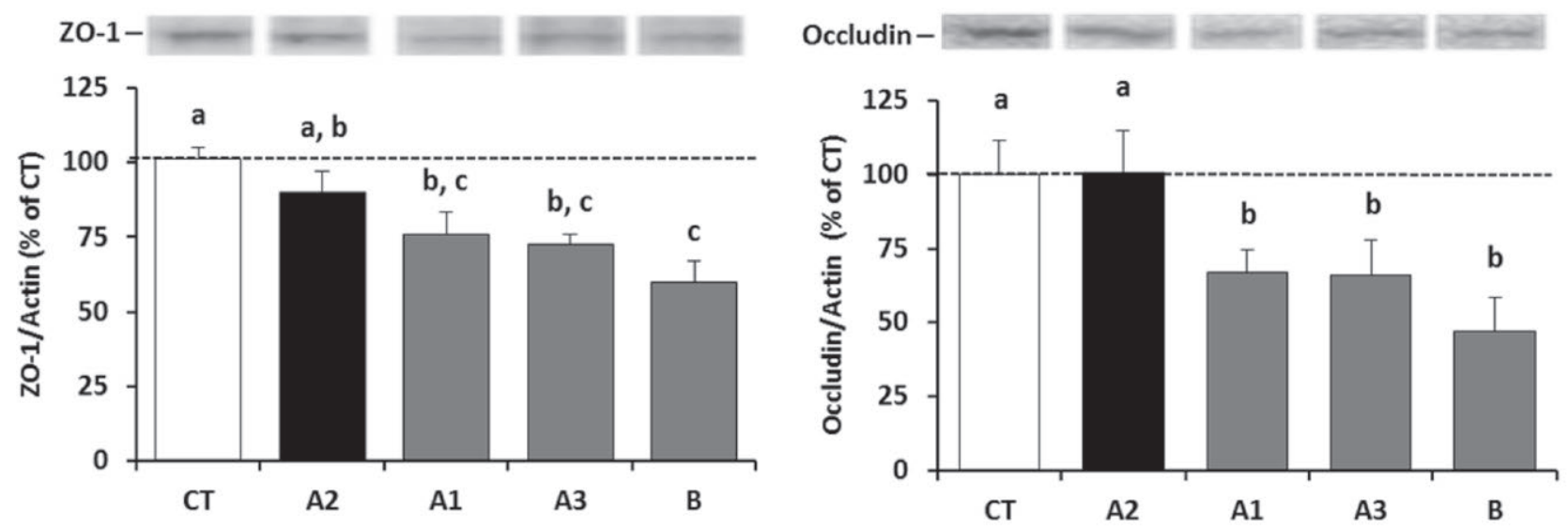

C

E
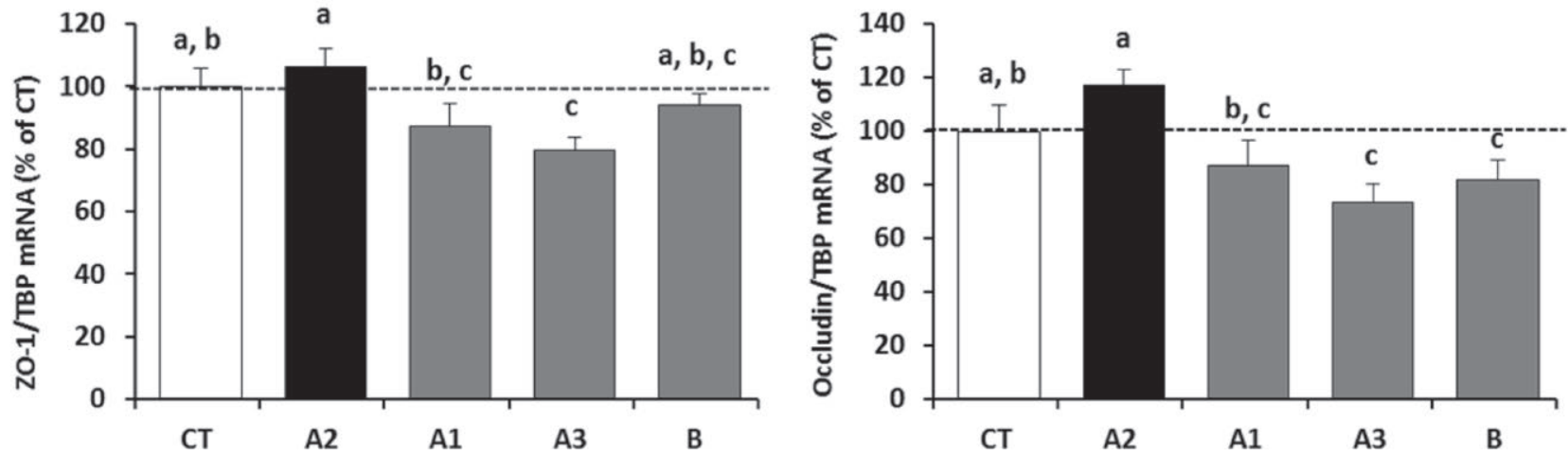

Figure 3. Peptide variants of $\beta$-casofensin $(0.1 \mu M)$ differently modulate intestinal permeability. Rat pups received a once-daily gavage (10 $\mu \mathrm{L} / \mathrm{g})$ of $\beta$-casofensin $(0.01 \mu M)$, peptide variants of $\beta$-casofensin $(0.01 \mu M)$, or drinking water (CT) from postnatal d 10 to 20 . (A) Paracellular permeability of jejunal segments in Ussing chambers (Harvard Apparatus, Holliston, MA). (B) Expression of ZO-1 was determined by Western blotting and normalization to the reference protein level (actin). Representative Western blot picture of ZO-1. (C) Real-time PCR analysis of ZO-1 mRNA. The expression of ZO-1 was normalized to the reference gene level $(T B P)$ in each sample. The results are expressed as percent of control rats. (D) Western blot analysis of occludin normalized to the reference protein level (actin). Representative Western blot picture of occludin. (E) Real-time PCR analysis of occludin mRNA. The expression of occludin was normalized to the reference gene level $(T B P)$ in each sample. The results are expressed as percent of control rats. Data are expressed as mean \pm SEM $(\mathrm{n}=8$ /group) and were analyzed by one-way ANOVA, followed by Tukey's multiple comparison test to differentiate the treatments. Means not sharing a common letter (a-c) differ significantly $(P<0.05)$. For instance, means labeled with "a" were significantly different from those labeled with "b," but were not different from those labeled with "a, b" in the present labeling system. CT = control; A2 = A2 variant; A1 = A1 variant; A3 = A3 variant; B = B variant; the horizontal dashed line indicates the control value. 
Table 2. Real-time reverse-transcription PCR analysis of Muc2, ZO-1, occludin, claudin-1, and claudin-7 from jejunum samples ${ }^{1}$

\begin{tabular}{lccccc}
\hline & \multicolumn{5}{c}{ Treatment $^{2}$} \\
\cline { 2 - 6 } Item & CT & A2 & A1 & A3 & B \\
\cline { 2 - 6 } Muc2 & $100.0 \pm 10.5^{\mathrm{b}}$ & $165.1 \pm 28.3^{\mathrm{a}}$ & $111.8 \pm 24.4^{\mathrm{ab}}$ & $76.1 \pm 15.1^{\mathrm{b}}$ & $64.8 \pm 12.8^{\mathrm{b}}$ \\
ZO-1 & $100.0 \pm 5.6^{\mathrm{ab}}$ & $109.4 \pm 6.4^{\mathrm{a}}$ & $87.3 \pm 7.2^{\mathrm{bc}}$ & $79.9 \pm 3.9^{\mathrm{c}}$ & $94.2 \pm 3.7^{\mathrm{c}}$ \\
Occludin & $100.0 \pm 9.9^{\mathrm{ab}}$ & $116.5 \pm 7.1^{\mathrm{a}}$ & $87.2 \pm 9.3^{\mathrm{bc}}$ & $73.5 \pm 6.6^{\mathrm{c}}$ & $82.0 \pm 7.3^{\mathrm{a}}$ \\
Claudin-1 & $100.0 \pm 19.7^{\mathrm{a}}$ & $103.1 \pm 12.5^{\mathrm{a}}$ & $65.8 \pm 14.0^{\mathrm{a}}$ & $66.1 \pm 23.3^{\mathrm{a}}$ & $101.9 \pm 30.0^{\mathrm{a}}$ \\
Claudin-7 & $100.0 \pm 6.4^{\mathrm{ab}}$ & $102.4 \pm 14.1^{\mathrm{a}}$ & $82.0 \pm 8.0^{\mathrm{bc}}$ & $65.1 \pm 6.2^{\mathrm{c}}$ & $70.1 \pm 5.0^{\mathrm{c}}$ \\
\hline
\end{tabular}

${ }^{\mathrm{a}-\mathrm{c}}$ Means within a row not sharing a common superscript differ significantly $(P<0.05)$. For instance, means labeled with "a" were significantly different from those labeled with "b" but were not different from those labeled with "ab" in the present labeling system.

${ }^{1}$ Gene expression was normalized to the reference gene level (TBP, TATA-box binding protein) in each sample. Results are mean \pm SEM and are expressed as percentage of controls $(C T), n=8 /$ group. The data were analyzed by one-way ANOVA, followed by Tukey's multiple comparison test to differentiate the treatments. ${ }^{2} \mathrm{CT}=$ control; $\mathrm{A} 2=\mathrm{A} 2$ variant; $\mathrm{A} 1=\mathrm{A} 1$ variant; $\mathrm{A} 3=\mathrm{A} 3$ variant; $\mathrm{B}=\mathrm{B}$ variant of $\beta-\mathrm{CN}$.

2011). It follows that the elucidation of the mechanism whereby the A1 variant decreased intestinal permeability is probably highly complex and would far exceed the scope of the present study.

In an attempt to explain the effect of an AA substitution in the peptide sequence, we modeled the possible tertiary structure of the 4 variants (Supplemental Fig-

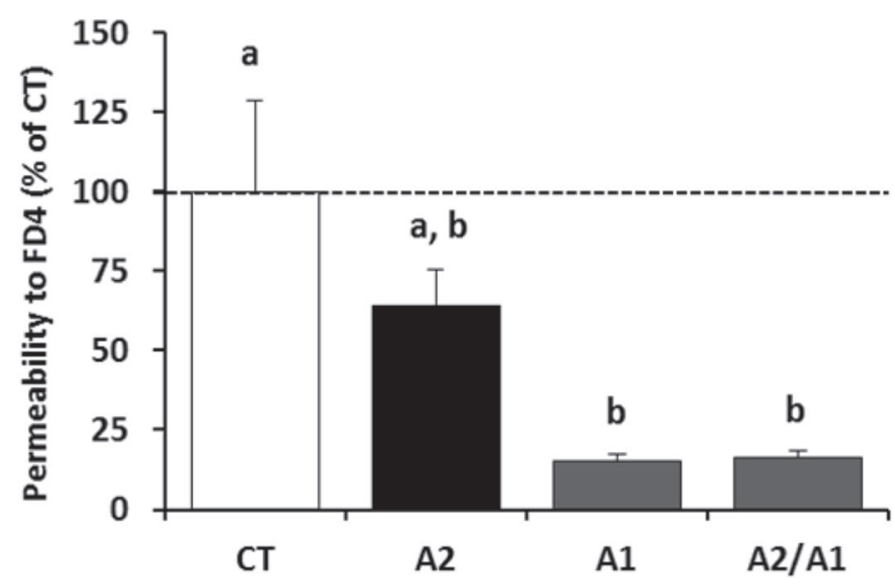

Figure 4. Effects of peptide variants of $\beta$-casofensin directly, tested ex vivo on jejunum of adult rats. Untreated adult rats were deeply anesthetized and jejunal samples were taken for study in Ussing chambers (Harvard Apparatus, Holliston, MA). After a 15-min stabilization in KRB $1 \times, \beta$-casofensin $(0.1 \mathrm{n} M)$, its variant A1 $(0.1 \mathrm{n} M)$, a mixture of variants $\mathrm{A} 1$ and $\mathrm{A} 2(50 / 50)$ at $0.1 \mathrm{n} M$, or $\mathrm{KRB} 1 \times$ (CT segment) was added to the mucosal compartment for a 30-min stimulation. The FD4 $(2 \mathrm{mg} / \mathrm{mL})$ was then added to the mucosal compartment for a 1-h stimulation to measure the jejunal paracellular permeability. Results are mean $\pm \mathrm{SEM}$, expressed as a percentage of the control group, $\mathrm{n}=$ 8 rats/group. The data were analyzed by one-way ANOVA, followed by Tukey's multiple comparison test to differentiate the treatments. Means not sharing a common letter $(\mathrm{a}, \mathrm{b})$ differ significantly $(P<$ $0.05) . \mathrm{CT}=$ control; $\mathrm{A} 2=\mathrm{A} 2$ variant; $\mathrm{A} 1=\mathrm{A} 1$ variant; $50 / 50=$ mixture of $\mathrm{A} 2$ and $\mathrm{A} 1$ variants at $0.1 \mathrm{n} M ; \mathrm{FD} 4=$ fluorescein isothiocyanate-labeled 4-kDa dextran (Sigma-Aldrich, St. Louis, MO); KRB $=$ Krebs-Ringer Bicarbonate Buffer (Sigma-Aldrich); the horizontal dashed line indicates the control value. ure S1; https://doi.org/10.3168/jds.2016-12067). In our model, $\beta$-casofensin (A2) and the A1 and A3 variants were composed of $1 \alpha$-helix of variable length and a large unstructured coil. The B variant was more structured with a short $\alpha$-helix and 2 short $\beta$-sheets. Consequently, surface properties of peptides were different, especially hydrophobic properties. Indeed, $\beta$-casofensin (A2) and its variants were mostly hydrophilic, with small hydrophobic patches, and only A1 variant showed a large hydrophobic patch that might constitute specific interaction site. The electrostatic surfaces were also different, but to a lesser degree. These structure models need to be confirmed, but they may explain the observed differences in effects between each of the variants.

It is now well accepted that methionine present in foods can be oxidized to methionine sulfoxide and sulfone during conservation and storage. Here, we showed that oxidation of the 2 methionines (Met102 and Met109) on $\beta$-casofensin modified its intestinal effects.

Table 3. Mean number of goblet cells per crypt-villus axis ${ }^{1}$

\begin{tabular}{lcccc}
\hline & \multicolumn{4}{c}{ Treatment $^{2}$} \\
\cline { 2 - 5 } Item & $\mathrm{CT}$ & $\mathrm{A} 2$ & $\mathrm{~A} 2 \mathrm{OX}$ & $\mathrm{A} 2 / \mathrm{A} 2 \mathrm{OX}$ \\
\hline Duodenum & $15.0 \pm 0.2^{\mathrm{b}}$ & $18.8 \pm 0.9^{\mathrm{a}}$ & $13.1 \pm 0.7^{\mathrm{b}}$ & $17.4 \pm 10.8^{\mathrm{a}}$ \\
Jejunum & $11.4 \pm 0.5^{\mathrm{d}}$ & $16.2 \pm 0.5^{\mathrm{b}}$ & $13.3 \pm 0.8^{\mathrm{c}}$ & $18.1 \pm 0.5^{\mathrm{a}}$ \\
Ileum & $11.7 \pm 0.5^{\mathrm{b}}$ & $11.7 \pm 0.3^{\mathrm{b}}$ & $12.7 \pm 0.6^{\mathrm{ab}}$ & $13.2 \pm 0.4^{\mathrm{a}}$ \\
\hline
\end{tabular}

$\overline{\mathrm{a}-\mathrm{d}}$ Means within a row not sharing a common superscript differ significantly $(P<0.05)$. For instance, means labeled with "a" were significantly different from those labeled with " $b$ " but were not different from those labeled with "ab" in the present labeling system.

${ }^{1}$ Results are expressed as mean \pm SEM, $n=8$ rat pups/group. The data were analyzed by one-way ANOVA, followed by Tukey's multiple comparison test to differentiate the treatments.

${ }^{2} \mathrm{CT}=$ control; $\mathrm{A} 2=\mathrm{A} 2$ variant; $\mathrm{A} 2 \mathrm{OX}=$ oxidized $\mathrm{A} 2$ variant; $\mathrm{A} 2 /$ $\mathrm{A} 2 \mathrm{OX}=$ mixture of $\mathrm{A} 2$ and $\mathrm{A} 2 \mathrm{OX}$ variants of $\beta-\mathrm{CN}$. 
A
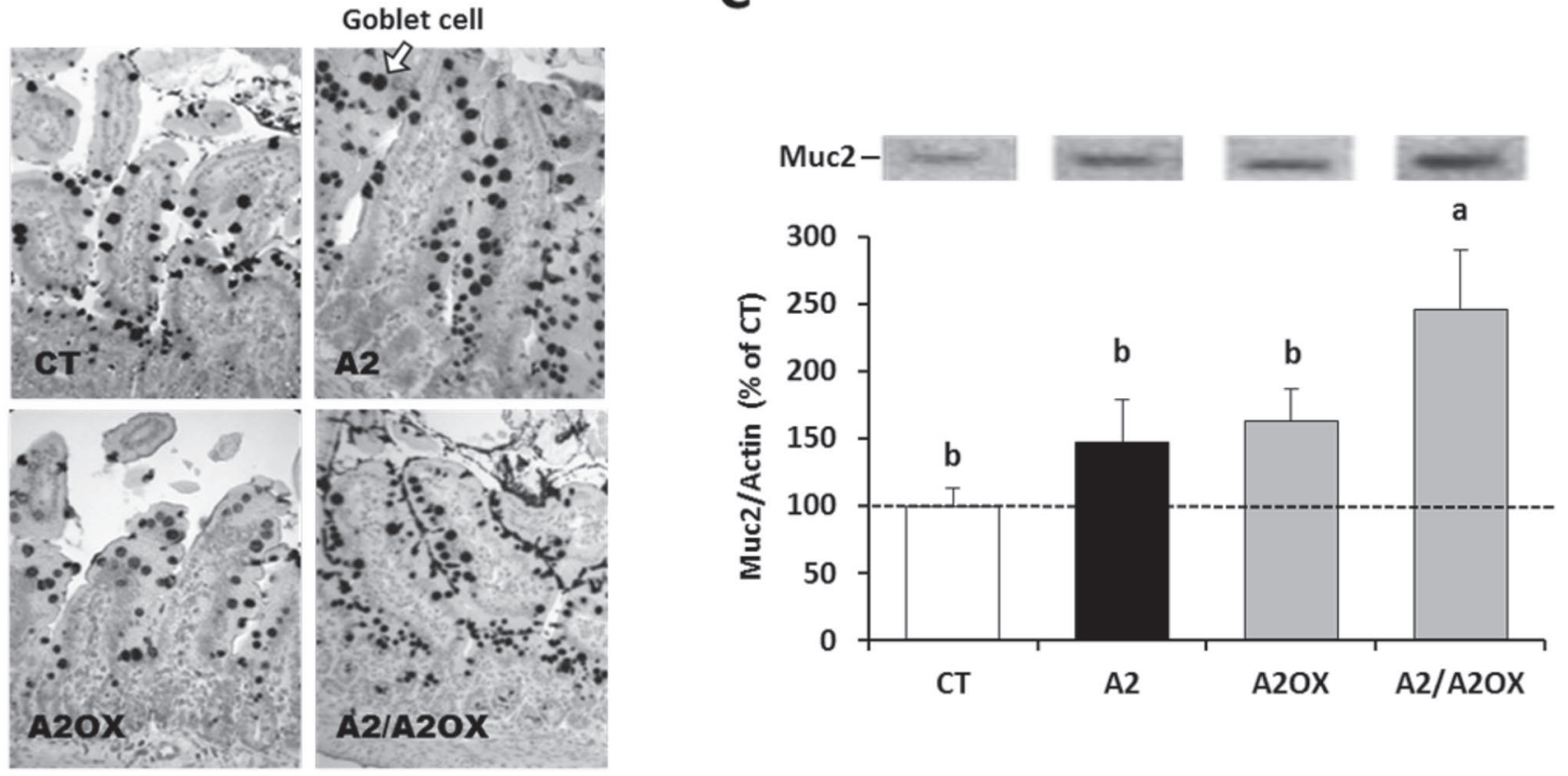

B

D
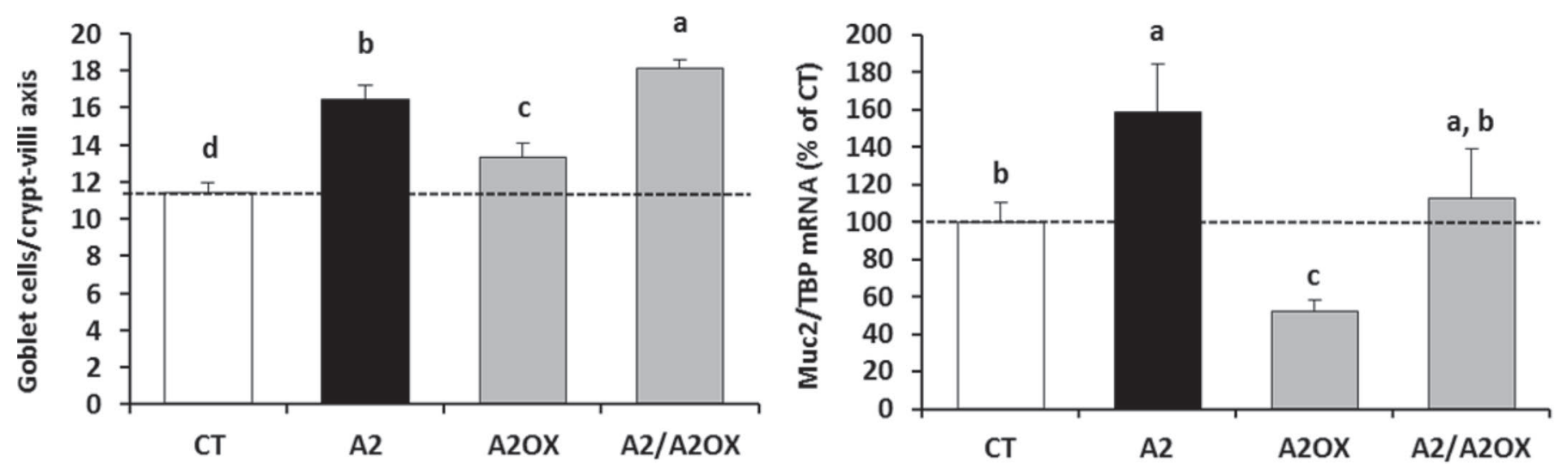

Figure 5. Oxidized $\beta$-casofensin $(0.1 \mu M)$ differently modulates intestinal goblet cells, intestinal permeability, and tight junction protein expression. Rat pups received a once-daily gavage $(10 \mu \mathrm{L} / \mathrm{g})$ of $\beta$-casofensin $(0.01 \mu M ; \mathrm{A} 2$ variant), oxidized $\beta$-casofensin $(0.01 \mu M)$, mixture of A2 variant and oxidized A2 variant $(0.01 \mu M)$, or drinking water (CT) from postnatal d 10 to 20. (A) Representative images from the jejunum of CT, A2, A2OX, and A2/A2OX rats. Numerous goblet cells were observed (arrow; original magnification $\times 20$ ). (B) Mean number of jejunal goblet cells per crypt-villus axis. For this purpose, 4 to 6 sections were analyzed per rat, and 200 to 300 goblet cells were counted per sample of intestine. (C) Expression of Muc2 was determined by Western blotting and normalization to the reference protein level (actin). Representative Western blot picture of Muc2. (D) Real-time PCR analysis of Muc2 mRNA. The expression of Muc2 was normalized to the reference gene level $(T B P)$ in each sample. The results are expressed as percent of control rats. Data are expressed as mean \pm SEM $(\mathrm{n}=8 /$ group) and were analyzed by one-way ANOVA, followed by Tukey's multiple comparison test to differentiate the treatments. Means not sharing a common letter $(\mathrm{a}-\mathrm{c})$ differ significantly $(P<0.05)$. For instance, means labeled with "a" were significantly different from those labeled with "b," but were not different from those labeled with "a,b" in the present labeling system. $\mathrm{CT}=$ control; $\mathrm{A} 2=\mathrm{A} 2$ variant; A2OX $=$ oxidized A2 variant; A2/A2OX $=$ mixture of $\mathrm{A} 2$ variant and oxidized A2 variant; the horizontal dashed line indicates the control value.

For example, A2OX has induced a significant decrease in jejunal claudin-1 and claudin-7 mRNA expression, which was not the case of A2. In addition, if administration of A2OX increased the number of jejunal goblet cells, this effect was significantly lower than that of
A2. It can be noted that the level of Muc2 mRNA was significantly higher in the jejunum of $\mathrm{CT}$ rats than in those of A2OX rats. This apparent discrepancy in results between quantitative RT-PCR and Western blot or histochemistry analysis might be related to the 
A

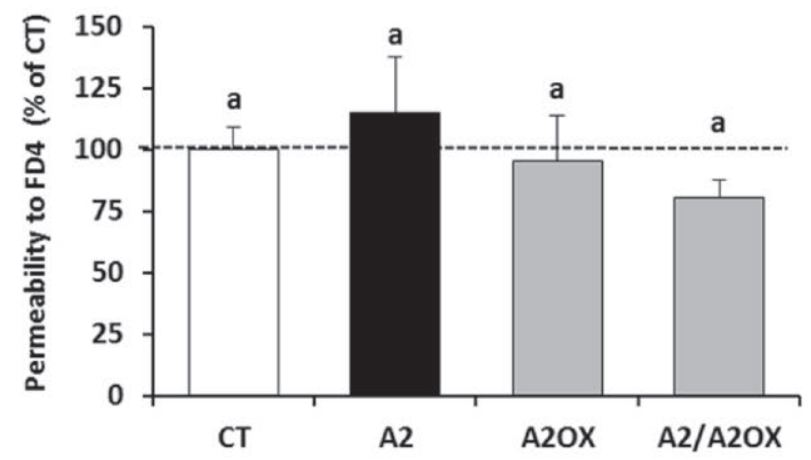

B

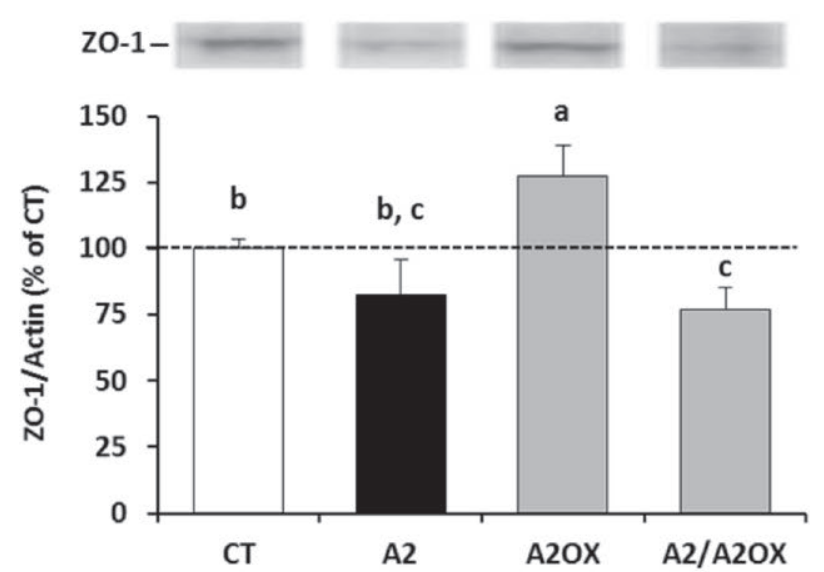

C

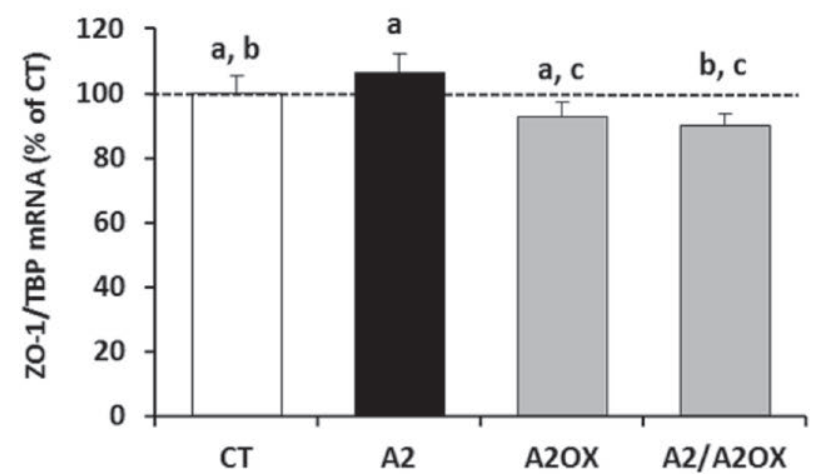

D
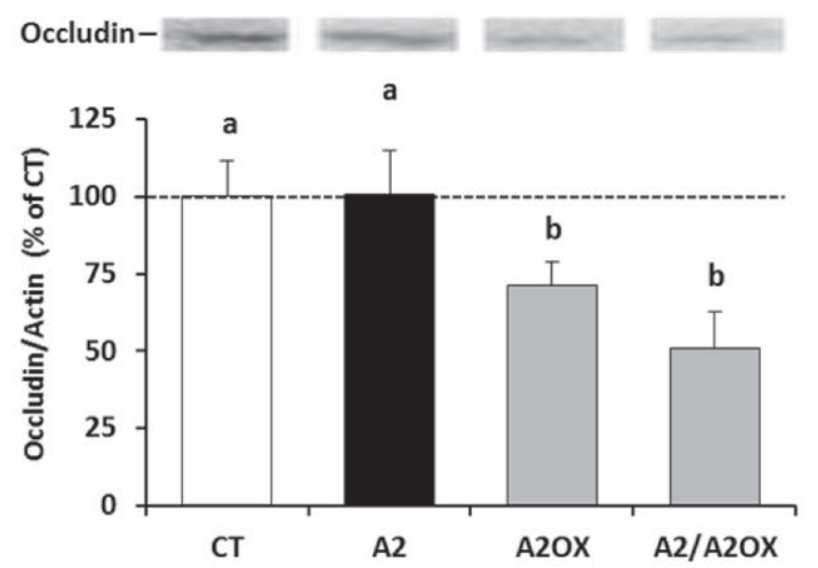

E

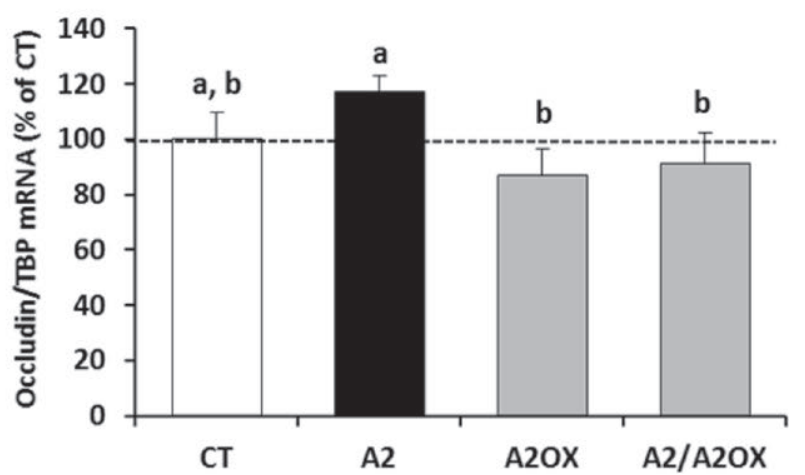

Figure 6. Oxidized $\beta$-casofensin $(0.1 \mu M)$ differently modulates intestinal permeability. Rat pups received a once-daily gavage $(10 \mu \mathrm{L} / \mathrm{g})$ of $\beta$-casofensin $(0.01 \mu M$; A2 variant), oxidized $\beta$-casofensin $(0.01 \mu M)$, mixture of A2 variant and oxidized A2 variant $(0.01 \mu M)$, or drinking water (CT) from postnatal d 10 to 20. (A) Paracellular permeability of jejunal segments in Ussing chambers (Harvard Apparatus, Holliston, MA). (B) Expression of ZO-1 was determined by Western blotting and normalization to the reference protein level (actin). Representative Western blot picture of ZO-1. (C) Real-time PCR analysis of ZO-1 mRNA. The expression of ZO-1 was normalized to the reference gene level (TBP) in each sample. The results are expressed as percent of control rats. (D) Western blot analysis of occludin normalized to the reference protein level (actin). Representative Western blot picture of occludin. (E) Real-time PCR analysis of occludin mRNA. The expression of occludin was normalized to the reference gene level $(T B P)$ in each sample. The results are expressed as percent of control rats. Data are expressed as mean \pm SEM ( $\mathrm{n}=8 /$ group) and were analyzed by one-way ANOVA, followed by Tukey's multiple comparison test to differentiate the treatments. Means not sharing a common letter $(\mathrm{a}-\mathrm{c})$ differ significantly $(P<0.05)$. For instance, means labeled with "a" were significantly different from those labeled with "b," but were not different from those labeled with "a, b" in the present labeling system. CT = control; A2 = A2 variant; $\mathrm{A} 2 \mathrm{OX}=$ oxidized A2 variant; A2/A2OX = mixture of A2 variant and oxidized A2 variant; the horizontal dashed line indicates the control value. 
Table 4. Real-time reverse-transcription PCR analysis of Muc2, ZO-1, occludin, claudin-1, and claudin-7 from jejunum samples ${ }^{1}$

\begin{tabular}{lcccc}
\hline & \multicolumn{3}{c}{ Treatment $^{2}$} \\
\cline { 2 - 5 } Item & $\mathrm{CT}$ & $\mathrm{A} 2$ & $\mathrm{~A} 2 \mathrm{OX}$ & A2/A2OX \\
\hline Muc2 & $100.0 \pm 10.5^{\mathrm{b}}$ & $165.1 \pm 28.3^{\mathrm{a}}$ & $51.9 \pm 6.1^{\mathrm{c}}$ & $112.3 \pm 26.4^{\mathrm{ab}}$ \\
ZO-1 & $100.0 \pm 5.6^{\mathrm{ab}}$ & $109.4 \pm 6.4^{\mathrm{a}}$ & $92.8 \pm 4.5^{\mathrm{ac}}$ & $89.8 \pm 3.8^{\mathrm{bc}}$ \\
Occludin & $100.0 \pm 9.9^{\mathrm{ab}}$ & $116.5 \pm 7.1^{\mathrm{a}}$ & $87.0 \pm 9.4^{\mathrm{b}}$ & $91.2 \pm 11.0^{\mathrm{b}}$ \\
Claudin-1 & $100.0 \pm 19.7^{\mathrm{a}}$ & $103.1 \pm 12.5^{\mathrm{a}}$ & $47.2 \pm 9.2^{\mathrm{b}}$ & $88.4 \pm 32.5^{\mathrm{ab}}$ \\
Claudin-7 & $100.0 \pm 6.4^{\mathrm{a}}$ & $102.4 \pm 14.1^{\mathrm{a}}$ & $76.3 \pm 5.5^{\mathrm{b}}$ & $77.4 \pm 6.0^{\mathrm{b}}$ \\
\hline
\end{tabular}

${ }^{\mathrm{a}-\mathrm{c}}$ Means within a row not sharing a common superscript differ significantly $(P<0.05)$. For instance, means labeled with "a" were significantly different from those labeled with "b" but were not different from those labeled with "ab" in the present labeling system.

${ }^{1}$ Gene expression was normalized to the reference gene level (TBP, TATA-box binding protein) in each sample. Results are mean \pm SEM and are expressed as percentage of controls, $n=8 /$ group. The data were analyzed by one-way ANOVA, followed by Tukey's multiple comparison test to differentiate the treatments.

${ }^{2} \mathrm{CT}=$ control; $\mathrm{A} 2=\mathrm{A} 2$ variant; $\mathrm{A} 2 \mathrm{OX}=$ oxidized $\mathrm{A} 2$ variant; $\mathrm{A} 2 / \mathrm{A} 2 \mathrm{OX}=$ mixture of $\mathrm{A} 2$ and oxidized $\mathrm{A} 2$ variants of $\beta-\mathrm{CN}$.

fact that the MUC2 polymers are synthesized and then stored awaiting the appropriate stimulus for secretion. This implies that mRNA studies may be misleading for the amount of mucin in goblet cells.

As for methionine oxidation, its effect on the bioactivity of $\beta$-casofensin could be due to the disturbance of its local secondary structure, induction of conformational disorder, and disturbance of key hydrophobic interactions (McCarthy et al., 2015). Indeed, the oxidation of methionines of proteins and peptides has been implicated in several biological processes, such as regulation of enzyme activities, cell signaling, or proteolytic degradation (Stadtman et al., 2003). For example, the oxidation of methionines on the Fc portion of IgG leads to reduced affinity for its receptor, as well as a faster plasma clearance (Stracke et al., 2014). Similarly, oxidation of either M109 or M124 in calmodulin alters its interaction with target proteins by perturbing the calcium-dependent structural shift (McCarthy et al., 2015). It is noteworthy, however, that a mixture of nonoxidized and oxidized $\beta$-casofensin had the same effect on goblet cells as $\beta$-casofensin only. This suggests that the oxidation of $\beta$-casofensin that might be induced by the storage of fermented milks would not disrupt its protective action on the intestinal barrier.

What effect might these results have on food and nutraceutical products derived from milk proteins? Although several studies have highlighted the health effect for humans of peptides derived from milk products (Seppo et al., 2003; Cadée et al., 2007), these studies did not take into account the existence of genetic polymorphisms of bovine milk proteins. Similarly, the oxidation state of these peptides is generally not known. Based on our results, the main variant of a milk protein contained in raw materials must be considered as an important parameter for the production of functional foods. It should be emphasized here that these amino acid substitutions have been identified in many milk proteins. For example, several genetic variants of $\alpha_{\mathrm{S} 1^{-}}$ $\mathrm{CN}(\mathrm{A}-\mathrm{H}), \kappa-\mathrm{CN}(\mathrm{A}-\mathrm{E}, \mathrm{F} 1-2, \mathrm{G} 1-2, \mathrm{H}-\mathrm{I}), \beta-\mathrm{LG}(\mathrm{A}-\mathrm{J}$, $\mathrm{W}$ ), or $\alpha$-lactalbumin $(\mathrm{A}-\mathrm{C})$ exist (Farrell et al., 2004). The amino acid substitutions observed in these proteins may therefore change the functionality of bioactive peptides derived from the proteins. Focusing on the main objective of our study, our results show that fermented milk containing the A2 variant (known as casofensin) is best placed to support intestinal protection.

\section{ACKNOWLEDGMENTS}

The authors thank AngloScribe (Calvisson, France) for its language assistance. This work was supported by Ingredia (Arras, France).

\section{REFERENCES}

Baker, N. A., D. Sept, S. Joseph, M. J. Holst, and J. A. McCammon. 2001. Electrostatics of nanosystems: application to microtubules and the ribosome. Proc. Natl. Acad. Sci. USA 98:10037-10041. https://doi.org/10.1073/pnas.181342398.

Barcelo, A., J. Claustre, F. Moro, J. A. Chayvialle, J. C. Cuber, and P. Plaisancie. 2000. Mucin secretion is modulated by luminal factors in the isolated vascularly perfused rat colon. Gut 46:218-224. https://doi.org/10.1136/gut.46.2.218.

Benoit, B., J. Bruno, F. Kayal, M. Estienne, C. Debard, R. Ducroc, and P. Plaisancie. 2015. Saturated and unsaturated fatty acids differently modulate colonic goblet cells in vitro and in rat pups. J. Nutr. 145:1754-1762. https://doi.org/10.3945/jn.115.211441.

Bessette, C., B. Benoit, S. Sekkal, J. Bruno, M. Estienne, J. Léonil, L. Ferrier, V. Théodorou, and P. Plaisancié. 2016. Protective effects of $\beta$-casofensin, a bioactive peptide from bovine $\beta$-casein, against indomethacin-induced intestinal lesions in rats. Mol. Nutr. Food Res. 60:823-833. https://doi.org/10.1002/mnfr.201500680.

Bobe, G., D. C. Beitz, A. E. Freeman, and G. L. Lindberg. 1998. Separation and quantification of bovine milk proteins by reversed-phase high-performance liquid chromatography. J. Agric. Food Chem. 46:458-463. https://doi.org/10.1021/jf970499p. 
Cadée, J., C. Chang, C. Chen, C. Huang, S. Chen, and C. Wang. 2007. Bovine casein hydrolysate (C12 Peptide) reduces blood pressure in prehypertensive subjects. Am. J. Hypertens. 20:1-5. https://doi. org/10.1016/j.amjhyper.2006.06.005.

Caroli, A. M., S. Chessa, and G. J. Erhardt. 2009. Invited review: Milk protein polymorphisms in cattle: Effect on animal breeding and human nutrition. J. Dairy Sci. 92:5335-5352. https://doi. org/10.3168/jds.2009-2461.

Dolinsky, T. J., P. Czodrowski, H. Li, J. E. Nielsen, J. H. Jensen G. Klebe, and N. A. Baker. 2007. PDB2PQR: Expanding and upgrading automated preparation of biomolecular structures for molecular simulations. Nucleic Acids Res. 35:W522-5. https://doi. org/10.1093/nar/gkm276.

Dolinsky, T. J., J. E. Nielsen, J. A. McCammon, and N. A. Baker. 2004. PDB2PQR: An automated pipeline for the setup of Poisson-Boltzmann electrostatics calculations. Nucleic Acids Res. 32:W665-7. https://doi.org/10.1093/nar/gkh381.

Efremov, R. G., A. Chugunov, T. Pyrkov, J. Priestle, A. Arseniev, and E. Jacoby. 2007. Molecular lipophilicity in protein modeling and drug design. Curr. Med. Chem. 14:393-415. https://doi. org/10.2174/092986707779941050.

European Commission. 2010. Directive 2010/63/EU. Legislation for the protection of animals used for scientific purposes. Horizontal legislation on the protection of animals used for scientific purposes. European Commission, Brussels, Belgium.

Farrell, H. M., R. Jimenez-Flores, G. T. Bleck, E. M. Brown, J. E. Butler, L. K. Creamer, C. L. Hicks, C. M. Hollar, K. F. Ng-KwaiHang, and H. E. Swaisgood. 2004. Nomenclature of the proteins of cows' milk-Sixth revision. J. Dairy Sci. 87:1641-1674. https:// doi.org/10.3168/jds.S0022-0302(04)73319-6.

Gallinat, J. L., S. Qanbari, C. Drögemüller, E. C. G. Pimentel, G. Thaller, and J. Tetens. 2013. DNA-based identification of novel bovine casein gene variants. J. Dairy Sci. 96:699-709. https://doi. org/10.3168/jds.2012-5908.

Humphrey, W., A. Dalke, and K. Schulten. 1996. VMD: Visual molecular dynamics. J. Mol. Graph. 14:33-38. https://doi. org/10.1016/0263-7855(96)00018-5.

Lee, S. H. 2015. Intestinal permeability regulation by tight junction: Implication on inflammatory bowel diseases. Intest. Res. 13:11. https://doi.org/10.5217/ir.2015.13.1.11.

Lien, S., and H. B. Lowman. 2003. Therapeutic peptides. Trends Biotechnol. 21:556-562. https://doi.org/10.1016/j.tibtech.2003.10.005.

Markov, A. G., A. Veshnyakova, M. Fromm, M. Amasheh, and S. Amasheh. 2010. Segmental expression of claudin proteins correlates with tight junction barrier properties in rat intestine. J. Comp. Physiol. B 180:591-598. https://doi.org/10.1007/s00360009-0440-7.

McCarthy, M. R., A. R. Thompson, F. Nitu, R. J. Moen, M. J. Olenek, J. C. Klein, and D. D. Thomas. 2015. Impact of methionine oxidation on calmodulin structural dynamics. Biochem. Biophys. Res. Commun. 456:567-572. https://doi.org/10.1016/j. bbrc.2014.11.091.

Mineta, K., Y. Yamamoto, Y. Yamazaki, H. Tanaka, Y. Tada, K. Saito, A. Tamura, M. Igarashi, T. Endo, K. Takeuchi, and S. Tsukita. 2011. Predicted expansion of the claudin multigene family. FEBS Lett. 585:606-612. https://doi.org/10.1016/j.febslet.2011.01.028.

Nagpal, R., P. Behare, R. Rana, A. Kumar, M. Kumar, S. Arora, F. Morotta, S. Jain, and H. Yadav. 2011. Bioactive peptides derived from milk proteins and their health beneficial potentials: an update. Food Funct. 2:18-27. /https://doi.org/10.1039/c0fo00016g.

Nongonierma, A. B., and R. J. FitzGerald. 2015. Bioactive properties of milk proteins in humans: A review. Peptides 73:20-34. https:// doi.org/10.1016/j.peptides.2015.08.009.

Noth, R., J. Lange-Grumfeld, E. Stüber, M.-L. Kruse, M. Ellrichmann, R. Häsler, J. Hampe, B. Bewig, P. Rosenstiel, S. Schreiber, and A. Arlt.. 2011. Increased intestinal permeability and tight junction disruption by altered expression and localization of occludin in a murine graft versus host disease model. BMC Gastroenterol. 11:109. https://doi.org/10.1186/1471-230X-11-109.

Pelaseyed, T., J. H. Bergström, J. K. Gustafsson, A. Ermund, G. M. H. Birchenough, A. Schütte, S. van der Post, F. Svensson, A. M. Rodríguez-Piñeiro, E. E. L. Nyström, C. Wising, M. E. V. Johansson, and G. C. Hansson. 2014. The mucus and mucins of the goblet cells and enterocytes provide the first defense line of the gastrointestinal tract and interact with the immune system. Immunol. Rev. 260:8-20. https://doi.org/10.1111/imr.12182.

Plaisancié, P., R. Boutrou, M. Estienne, G. Henry, J. Jardin, A. Paquet, and J. Léonil. 2015. ß-Casein(94-123)-derived peptides differently modulate production of mucins in intestinal goblet cells. J. Dairy Res. 82:36-46. https://doi.org/10.1017/S0022029914000533.

Plaisancié, P., J. Claustre, M. Estienne, G. Henry, R. Boutrou, A. Paquet, and J. Léonil. 2013. A novel bioactive peptide from yoghurts modulates expression of the gel-forming MUC2 mucin as well as population of goblet cells and Paneth cells along the small intestine. J. Nutr. Biochem. 24:213-221. https://doi.org/10.1016/j. jnutbio.2012.05.004.

Pyrkov, T. V., A. O. Chugunov, N. A. Krylov, D. E. Nolde, and R. G. Efremov. 2009. PLATINUM: A web tool for analysis of hydrophobic/hydrophilic organization of biomolecular complexes. Bioinformatics 25:1201-1202. https://doi.org/10.1093/bioinformatics/ btp111.

Schulzke, J.-D., A. H. Gitter, J. Mankertz, S. Spiegel, U. Seidler, S. Amasheh, M. Saitou, S. Tsukita, and M. Fromm. 2005. Epithelial transport and barrier function in occludin-deficient mice. Biochim. Biophys. Acta 1669:34-42. https://doi.org/10.1016/j. bbamem.2005.01.008.

Schulzke, J.-D., D. Günzel, L. J. John, and M. Fromm. 2012. Perspectives on tight junction research. Ann. N. Y. Acad. Sci. 1257:1-19. https://doi.org/10.1111/j.1749-6632.2012.06485.x.

Seppo, L., T. Jauhiainen, T. Poussa, and R. Korpela. 2003. A fermented milk high in bioactive peptides has a blood pressure-lowering effect in hypertensive subjects. Am. J. Clin. Nutr. 77:326-330.

Shen, Y., J. Maupetit, P. Derreumaux, and P. Tufféry. 2014. Improved PEP-FOLD approach for peptide and miniprotein structure prediction. J. Chem. Theory Comput. 10:4745-4758. https://doi. org $/ 10.1021 /$ ct500592m

Stadtman, E. R., J. Moskovitz, and R. L. Levine. 2003. Oxidation of methionine residues of proteins: Biological consequences. Antioxid. Redox Signal. 5:577-582. https://doi org/10.1089/152308603770310239.

Stracke, J., T. Emrich, P. Rueger, T. Schlothauer, L. Kling, A. Knaupp, H. Hertenberger, A. Wolfert, C. Spick, W. Lau, G. Drabner, U. Reiff, H. Koll, and A. Papadimitriou. 2014. A novel approach to investigate the effect of methionine oxidation on pharmacokinetic properties of therapeutic antibodies. MAbs 6:1229-1242. https:// doi.org/10.4161/mabs.29601.

Thevenet, P., Y. Shen, J. Maupetit, F. Guyon, P. Derreumaux, and P. Tuffery. 2012. PEP-FOLD: An updated de novo structure prediction server for both linear and disulfide bonded cyclic peptides. Nucleic Acids Res. 40:W288-W293. http://dx.doi.org/https://doi. org/10.1093/nar/gks419.

Tulipano, G., O. Bulgari, S. Chessa, A. Nardone, D. Cocchi, and A. Caroli. 2010. Direct effects of casein phosphopeptides on growth and differentiation of in vitro cultured osteoblastic cells (MC3T3E1). Regul. Pept. 160:168-174. https://doi.org/10.1016/j. regpep.2009.11.018.

Umeda, K., T. Matsui, M. Nakayama, K. Furuse, H. Sasaki, M. Furuse, and S. Tsukita. 2004. Establishment and characterization of cultured epithelial cells lacking expression of ZO-1. J. Biol. Chem. 279:44785-44794. https://doi.org/10.1074/jbc.M406563200.

Weimann, C., H. Meisel, and G. Erhardt. 2009. Short communication: Bovine $\mathrm{k}$-casein variants result in different angiotensin I converting enzyme (ACE) inhibitory peptides. J. Dairy Sci. 92:1885-1888. https://doi.org/10.3168/jds.2008-1671. 